IZA DP No. 8421

Career Wage Profiles and the Minimum Wage

Kerry Papps

August 2014

Forschungsinstitut zur Zukunft der Arbeit Institute for the Study of Labor 


\title{
Career Wage Profiles and the Minimum Wage
}

\author{
Kerry Papps \\ University of Bath \\ and IZA
}

\section{Discussion Paper No. 8421 \\ August 2014}

IZA
P.O. Box 7240
53072 Bonn
Germany

Phone: +49-228-3894-0

Fax: +49-228-3894-180

E-mail: iza@iza.org

\begin{abstract}
Any opinions expressed here are those of the author(s) and not those of IZA. Research published in this series may include views on policy, but the institute itself takes no institutional policy positions. The IZA research network is committed to the IZA Guiding Principles of Research Integrity.

The Institute for the Study of Labor (IZA) in Bonn is a local and virtual international research center and a place of communication between science, politics and business. IZA is an independent nonprofit organization supported by Deutsche Post Foundation. The center is associated with the University of Bonn and offers a stimulating research environment through its international network, workshops and conferences, data service, project support, research visits and doctoral program. IZA engages in (i) original and internationally competitive research in all fields of labor economics, (ii) development of policy concepts, and (iii) dissemination of research results and concepts to the interested public.
\end{abstract}

IZA Discussion Papers often represent preliminary work and are circulated to encourage discussion. Citation of such a paper should account for its provisional character. A revised version may be available directly from the author. 
IZA Discussion Paper No. 8421

August 2014

\section{ABSTRACT}

\section{Career Wage Profiles and the Minimum Wage}

A model of on-the-job training in the presence of a minimum wage is presented. This predicts that the minimum wage will have a negative effect on a worker's subsequent wage growth when the labour market is competitive but a U-shaped effect when it is not competitive. This prediction is then tested using data from the Annual Survey of Hours and Earnings in the United Kingdom. Workers who were affected by the minimum wage before age 22 are found to have significantly lower wage growth later in life than others, but only if they worked on jobs that were not covered by a collective labour agreement. Evidence suggests that this difference in wage growth reflects differences in productivity between workers. The results reconcile previous theoretical predictions by Becker and Acemoglu and Pischke.

JEL Classification: J38

Keywords: minimum wages, wage growth, competitiveness

Corresponding author:

Kerry L. Papps

Department of Economics

University of Bath

Bath, BA2 7AY

United Kingdom

E-mail:k.I.papps@bath.ac.uk

\footnotetext{
* This research is based on a report commissioned by the Low Pay Commission. The author would like to thank Paul Gregg, Rebecca Riley, Alan Manning, Tim Butcher, Bob Elliott, Steve Machin, Felix Ritchie and participants at the Low Pay Commission Research Symposium, September 2013, for their helpful suggestions. In addition, he is grateful to the staff of the UK Data Archive for their assistance in accessing and analysing the ASHE data.
} 


\section{Introduction}

Although it has been extensively debated by economists, a growing consensus has formed that minimum wage laws have little effect on employment levels, even though they raise hourly wage rates (Brown 1999). This implies either that employers are able to recoup the costs associated with the minimum wage by economising on aspects of the total employment package other than the basic hourly wage or that the labour market is not perfectly competitive, so that employers can absorb the cost increase and still make excess profits. One way that employers might attempt to offset increases in the minimum wage is by adjusting the amount of on-the-job training offered to workers. In a seminal paper, Becker (1962) established that when the labour market is competitive, firms will only pay for training if it is specific to the firm. This implies that firms should cut back on training whenever they are compelled to raise wages due to the minimum wage (Rosen 1972). More recent work has shown that the situation is more complex when there is not perfect competition in the labour market (Acemoglu and Pischke 1999) and that firms might actually raise training for some workers when the minimum wage increases (Acemoglu and Pischke 2003).

The nature of the relationship between the minimum wage and training has important implications for policy makers. The fact that on-the-job training has a large effect on subsequent wage growth and most training takes place during the early stages of workers' careers is often given as a justification for allowing young workers to be paid wages less than the adult minimum (Eyraud and Saget 2005). However, if Acemoglu and Pischke's model applies, such 'youth rates' or 'sub-minimum wages' may have the opposite effect to that intended and may hinder young workers' abilities to move up the wage distribution over their working lives.

Previous empirical research has failed to uncover a significant link between the minimum wage and the prevalence of on-the-job training. Studies have also examined whether the minimum wage affects wage growth rates, which should follow if training levels are adjusted. Some of these have reported a negative relationship, while others have found insignificant results. Acemoglu and Pischke's work points to the crucial importance of the level of competitiveness in the labour market. Hence, the relationship between the minimum wage and training is likely to vary both between and within countries, according to how closely the labour market resembles a case of perfect competition. Although Acemoglu and Piscke looked at how training differs across industries with different degrees of competitiveness, no previous study has 
directly tested whether the nature of the labour market in which an individual minimum wage job is located affects wage growth later in a worker's career.

This paper examines whether the competing theories of Becker and Acemoglu and Pischke can be reconciled. A simple model of on-the-job training is presented, which implies that the minimum wage should have different effects on a worker's subsequent rate of wage growth depending on whether the worker is employed in the competitive or non-competitive sector of the labour market. Highly accurate longitudinal data from the Annual Survey of Hours and Earnings in the United Kingdom are then used to test these predictions. A natural experiment approach is taken, which involves comparing the wage growth of otherwise identical different workers who were affected by the youth minimum wage to different degrees because they entered the labour market at different times. As well as providing the first evidence of how the effects of the minimum wage on wage growth vary by labour market structure, the paper provides evidence on the efficacy of youth rates in raising the wages of low-wage workers over their entire working lives.

\section{Background}

Early empirical studies of the training effects of the minimum wage used workers' wage growth rates as a proxy for their level of on-the-job training. These studies found a negative relationship between the minimum wage and wage growth (Leighton and Mincer 1981; Lazear and Miller 1981; Hashimoto 1982). Grossberg and Sicilian (1999) noted that there are three main problems with using wage growth as a proxy for training: wage growth depends on the fraction of job-specific training that takes place and the relative bargaining power of firms and workers; other theories of pay structure (such as Lazear's (1979) delayed compensation model) imply wage changes that are independent of productivity; and using wage changes across all workers fails to account for the fact that most training occurs early in a worker's career. As a consequence of these problems, more recent studies have used direct measures of training participation. Some of these found negative effects (Schiller 1994; Neumark and Wascher 2001), whereas others found an insignificant relationship (Simpson 1984; Grossberg and Sicilian 1999; Acemoglu and Pischke 2003; Arulampalam et al. 2004; Fairris and Pedace 2004).

Although the use of direct information on training avoids the issues noted by Grossberg and Sicilian, it suffers from a number of other problems. Firstly, the 
available training data are almost always poor measures of the breadth and extent of actual activities that raise a worker's future productivity. Secondly, the benefits of some training might be very small or might be primarily received by firms, meaning that they have little direct effect on a worker's welfare. Finally, a narrow focus on training is unable to provide evidence to policymakers of how much the introduction of a youth minimum wage rate might raise young workers' incomes over their entire careers.

For these reasons, this paper revisits the link between minimum wages and subsequent wage growth, using modern panel data and a natural experiment design to address Grossberg and Sicilian's concerns. Furthermore, unlike the earlier studies that took the wage growth approach, the focus here is on the difference in wage growth between minimum wage workers in two sectors of the economy. The only previous study to analyse how the effects of the minimum wage on training vary by level of labour market competitiveness was Acemoglu and Pischke (2003), who used industry wage differentials as a measure of competitiveness. They found some weak evidence that training is positively related to the minimum wage among workers in less competitive sectors of the United States economy. However, Acemoglu and Pischke were restricted by their data source (the National Longitudinal Survey of Youth 1979) to focus on training undertaken between ages 22 and 29, which is likely to be too late to capture most of the general on-the-job training undertaken by minimum wage workers. These data also provided rather imprecise measures of a worker's hourly wage (and hence whether the worker was bound by the minimum wage), as they rely on retrospective survey responses.

\section{The United Kingdom National Minimum Wage}

A national minimum wage was introduced in the United Kingdom on 1 April 1999, covering all workers aged 18 and over. Initially, this consisted of an adult rate for those aged 22 and over, set at £3.60, and a development rate for those aged 18-21, set at £3.00. On 1 October 2004, a (lower) rate was introduced for workers aged 1617. On 1 October 2010, the age limit for the adult rate was lowered to 21 and an apprentice rate was introduced, for apprentices aged 16-18 or those aged 19 and over and in their first year of their apprenticeship. The minimum wage rates are reviewed each year by the Low Pay Commission, an independent advisory body which makes recommendations to the Government. The Government has chosen to increase all of 
the rates each October since 2000, but by varying amounts each year. By October 2010 , the adult rate was $£ 5.93$, the development rate was $£ 4.92$, the 16 - 17 rate was $£ 3.64$ and the apprentice rate was $£ 2.50$.

The minimum wage applies to all workers who have a contract to do work personally, rather than for a customer or client. Hence, it applies to casual workers, temporary workers and agency workers, but not to the self employed. For the purposes of the minimum wage, a worker's hourly wage is calculated by dividing his/her total gross pay for the reference period (normally a month) by total hours worked during that period. Incentive pay is included in this calculation, but not premium pay for shift or overtime work. All time spent doing on-the-job training (and time spent travelling to and from it) is subject to the minimum wage.

\section{Theory}

Consider a model in which each worker, indexed by $i$, is assumed to work in the labour market for $T+1$ periods. A worker's marginal revenue product is assumed to consist of a fixed component $\mu$, which captures differences in productivity between workers, and a time-varying component $\gamma$, which captures the fact that productivity initially increases over the life cycle, before falling. Workers are able to engage in onthe-job training; however, the decision of whether to provide this is made by the firm. Training is assumed to take place during the initial period of employment only and to produce human capital gains for the following $T$ periods. The cost of training manifests itself as a fall of $\theta$ in marginal revenue product in the first period, where $\theta \in\left[0, \theta_{\max }\right]$. The benefits of training are a rise of $f_{t}(\theta)$ in marginal revenue product in periods 1 to $T$. To ease exposition, the following functional form is used:

$f_{t}\left(\theta_{i}\right)=\beta_{t} \theta_{i}$, where $\beta_{t+1}>\beta_{t}$ and $\Delta \beta_{t+1}<\Delta \beta_{t}, \forall t$.

Equation 1 is consistent with a setting in which the benefits from training (in terms of increases in marginal revenue product) are realised over multiple periods, but that the largest gains come first and that eventually the growth rate in marginal revenue product falls to that of untrained workers.

All training is assumed to be general in nature and, hence, perfectly transferable to other jobs. There is an exogenous job separation rate of $p$ and a discount rate of $r$. It will be assumed that the marginal cost of training will be outweighed by the expected marginal benefits of training after $\hat{t}$ post-training periods (where $\hat{t}<T$ ): 
$\sum_{t=1}^{\hat{t}} \frac{(1-p)^{t} \beta_{t}}{(1+r)^{t}}>1$

It is assumed that there are two sectors in the labour market: a (perfectly) competitive sector and a non-competitive sector and that workers can freely move between sectors. The situation in each sector is discussed in turn.

\section{Competitive sector}

As in Becker's (1962) well-known analysis, workers in competitive labour markets bear the full cost of general training, through lower wages, but also receive all the benefits of that training. Therefore, a worker's wage in any period is given by:

$$
w_{i t}=\left\{\begin{array}{ll}
\mu_{i}+\gamma_{t}-\theta_{i} & \text { if } t=0 \\
\mu_{i}+\gamma_{t}+\beta_{t} \theta_{i} & \text { if } t=1, \ldots, T
\end{array} .\right.
$$

Suppose initially that there is no minimum wage. The level of training has no effect on a firm's profits, but the firm can maximise their workers' utility by choosing the optimal level of training:

$$
\max _{i}-\theta_{i}+\sum_{t=1}^{T} \frac{(1-p)^{t} \beta_{t} \theta_{i}}{(1+r)^{t}}
$$

Given the assumption made about training costs in equation 2, it must be the case that all firms choose the maximum amount of training available, $\theta_{\max }$, which is the same for all workers. ${ }^{1}$ From equation 3 , the wage in the initial period is $w_{i 0}^{*}=\mu_{i}+\gamma_{0}-\theta_{\max }$.

Suppose now that a minimum wage $\bar{w}$ is introduced. Obviously, if the minimum wage is set below the competitive wage, it will have no effect on the amount of training taking place. However, if $\bar{w}>\mu_{i}+\gamma_{0}-\theta_{\max }$, the minimum wage will prevent the optimal level of training from taking place, because the firm's profits will fall in this case. Instead, the firm will be willing to provide training so long as it does not lower profits, as follows:

$$
\max _{\theta_{i}}-\theta_{i}+\sum_{t=1}^{T} \frac{(1-p)^{t} \beta_{t} \theta_{i}}{(1+r)^{t}} \text {, subject to } \mu_{i}+\gamma_{0}-\theta_{i} \geq \bar{w} \text {. }
$$

\footnotetext{
${ }^{1}$ This contrasts with Acemoglu and Pischke's (2003) model, which assumed that no training takes place in the absence of a minimum wage.
} 
Solving this problem using the appropriate Kuhn-Tucker conditions yields the following solution:

$\bar{\theta}_{i}=\mu_{i}+\gamma_{0}-\bar{w}$.

Equation 6 represents a case of perfect crowding out between the minimum wage and the amount of training. As Becker (2009) explained, firms "provide general training only if they [do] not have to pay any of the costs”.

Note that the following relationship holds between a worker's wage and his/her level of training in the constrained and unconstrained states:

$$
\begin{aligned}
\bar{w}-w_{i 0}^{*} & =\bar{w}-\left(\mu_{i}+\gamma_{0}-\theta_{\max }\right) \\
& =\theta_{\max }-\bar{\theta}_{i} .
\end{aligned}
$$

Therefore, the optimal level of training can be written:

$\bar{\theta}_{i}=\left\{\begin{array}{ll}\theta_{\max } & \text { if } \bar{w} \leq w_{i 0}^{*} \\ \theta_{\max }-\bar{w}+w_{i 0}^{*} & \text { if } w_{i 0}^{*}<\bar{w} \leq \mu_{i}+\gamma_{0}\end{array}\right.$.

If $\bar{w}>\mu_{i}+\gamma_{0}$, the firm will make negative profits even if it eliminates training completely, so it should choose to lay off the worker.

\section{Non-competitive sector}

Now consider the case where workers and firms bargain over some total surplus. ${ }^{2}$ If workers are always able to find jobs in the competitive sector, the firm must pay them at least their marginal revenue product each period. However, as in Acemoglu and Pischke (2003), it will be assumed for simplicity that firms receive the entire remaining surplus and that this is equal to $\phi$ per worker each period. (This does not change the main result.)

Since the firm earns the same rent each period, regardless of the level of training, the wage schedule will be the same as under competition (equation 3). Furthermore, in the absence of a minimum wage, the optimal level of training will be the same as in the competitive sector (that is, $\theta_{\max }$ ). However, when a minimum wage is imposed, the situation diverges from the competitive case. The firm's profit maximisation problem can now be written as follows:

\footnotetext{
${ }^{2}$ The presence of a surplus implies that the firm operates in an imperfectly competitive product market and implicitly assumes that the workers and firms are bargaining over points on a vertical contract curve.
} 


$$
\begin{gathered}
\max _{\theta_{i}} \mu_{i}+\gamma_{0}+\phi-\theta_{i}-w_{i 0}+\sum_{t=1}^{T} \frac{(1-p)^{t}\left(\mu_{i}+\gamma_{t}+\phi+\beta_{t} \theta_{i}-w_{i t}\right)}{(1+r)^{t}}, \text { subject to } \\
\quad w_{i 0}=\max \left\{\mu_{i}+\gamma_{0}-\theta_{i}, \bar{w}\right\} \text { and } w_{i t}=\max \left\{\mu_{i}+\gamma_{t}+\beta_{t} \theta_{i}, \bar{w}\right\}, \forall t=1, \ldots, T .
\end{gathered}
$$

Because both $\gamma$ and $\beta$ increase over time, as the minimum wage rises, it will bind first in period 0 , then in period 1 and so on. If it binds only in period 0 , the optimal level of training will be the same as in the competitive case:

$$
\bar{\theta}_{i}=\mu_{i}+\gamma_{0}-\bar{w}=\theta_{\max }-\bar{w}+w_{i 0}^{*} \text {. }
$$

Once again, there is a negative relationship between training and the minimum wage. However, this time, once the minimum wage rises so high that training is cut to zero, the firm will retain the worker because it still makes excess profits from doing so. Further minimum wage increases will have no effect on training, until the minimum wage binds in period $\hat{t}$. When this happens, the firm will find it profitable to increase training up to the point where the worker's post-training wage is just equal to the minimum wage, namely:

$$
\bar{\theta}_{i}=\frac{\bar{w}-\mu_{i}-\gamma_{\hat{t}}}{\beta_{\hat{t}}}=\frac{\bar{w}-w_{i 0}^{*}+\gamma_{0}-\gamma_{\hat{t}}-\theta_{\max }}{\beta_{\hat{t}}} .
$$

As in Acemoglu and Pischke (2003), the level of training is now positively related to the minimum wage, because by increasing training, firms can raise productivity in the following period, knowing that they can continue to pay the minimum wage regardless.

Therefore, a complete description of the firm's decision is that it will provide the following amount of training:

$$
\bar{\theta}_{i}=\left\{\begin{array}{ll}
\theta_{\max } & \text { if } \bar{w} \leq w_{i 0}^{*} \\
\theta_{\max }-\bar{w}+w_{i 0}^{*} & \text { if } w_{i 0}^{*}<\bar{w} \leq \mu_{i}+\gamma_{0} \\
0 & \text { if } \mu_{i}+\gamma_{0}<\bar{w} \leq \mu_{i}+\gamma_{t^{*}} \\
\frac{\bar{w}-w_{i 0}^{*}+\gamma_{0}-\gamma_{\hat{t}}-\theta_{\max }}{\beta_{\hat{t}}} & \text { if } \mu_{i}+\gamma_{t^{*}}<\bar{w} \leq \mu_{i}+\gamma_{t^{*}}+\beta_{t^{*}} \theta_{\max } \\
\theta_{\max } & \text { if } \mu_{i}+\gamma_{t^{*}}+\beta_{t^{*}} \theta_{\max }<\bar{w}
\end{array},\right.
$$

provided that it makes non-negative profits from doing so, that is:

$\mu_{i}+\gamma_{0}+\phi-\bar{\theta}_{i}-w_{i 0}+\sum_{t=1}^{T} \frac{(1-p)^{t}\left(\mu_{i}+\gamma_{t}+\phi+\beta_{t} \bar{\theta}_{i}-w_{i t}\right)}{(1+r)^{t}} \geq 0$.

When $\phi=0$, equation 13 reduces to the profit constraint for the competitive sector: $\mu_{i}+\gamma_{0}-\theta_{i} \geq \bar{w}$. 
Figure 1

Predicted relationship between wage growth and wage gap in period 0

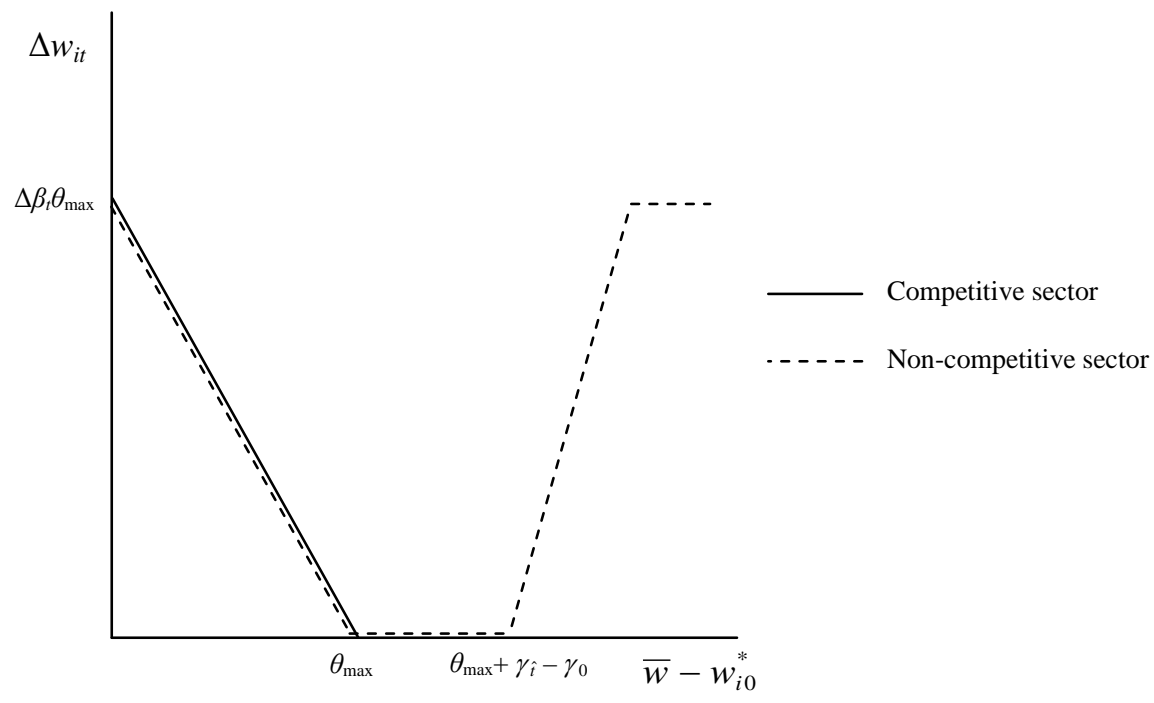

\section{Equilibrium wage growth}

The change in a worker's wage between any two post-training periods is given by the following:

$w_{i(t+1)}-w_{i t}=\left(\beta_{t+1}-\beta_{t}\right) \bar{\theta}_{i}+\gamma_{t+1}-\gamma_{t}$.

In the competitive sector, the optimal level of training is given by equation 8 , therefore a worker's 'wage gap' in period $0\left(\bar{w}-w_{i 0}^{*}\right)$ should have a negative effect on his/her subsequent wage growth. In the non-competitive sector, the optimal training level is given by equation 12 and the period 0 wage gap may have a negative or a positive marginal effect on wage growth, depending on how large the gap is. The relationship between wage growth and the wage gap in each sector is depicted in Figure 1. If it is set at a low level, a minimum wage will have the same negative effect on wage growth in each sector. However, if the minimum wage is set at a high level, it may lower wage growth by only a small amount in the non-competitive sector.

\section{Data}

The analysis draws on data from the Annual Survey of Hours and Earnings (ASHE), which is an annual survey that collects data on the wages, work hours and other employment arrangements of around 1\% of the UK working population (Office for National Statistics 2013). Basic additional information, such as age and sex, is also 
included. The ASHE was introduced in 2004 and replaced the New Earnings Survey (NES). However, by applying ASHE methodologies to NES data for the 1997-2003 period, the Office for National Statistics has produced ASHE datasets for 1997 onwards. The analysis in this study uses data for 1997-2011.

The ASHE sample is drawn from HM Revenue and Customs’ Pay As You Earn (PAYE) register, based on the last two digits of a worker's National Insurance Number. Survey forms are sent to all employers of the selected workers to complete. The questions in the ASHE refer to a reference week, which is in early April of each year. Since the responses are provided by employers rather than by employees, the ASHE wage and hours data are considered to be highly accurate, compared to traditional household surveys and censuses.

If a person does not work in a given year, he/she will not appear in the dataset. Therefore, the only way to determine whether someone has moved out of employment is by their absence from the data in a given year. Obviously, this will also include people who have moved abroad or died. However, as long as the fraction of people making these transitions is constant across the wage distribution, this will not bias the results from the empirical strategy outlined in the next section. Workers might also be absent from the ASHE if an employer fails to respond to the questionnaire or if they are not included in the PAYE register because their earnings fall below the National Insurance Lower Earnings Limit.

The sample is restricted to those who were aged between 22 and 31, had full-time jobs and who were employed in the following year. In cases where a person reported more than one full-time job in a year, only the job on which he/she worked the most hours is included. The period during which people are subject to the $16-17$ year-old rate or the development rate for ages 18-21 (or 18-20 since 2010) is assumed to be the phase of a worker's career in which on-the-job training takes place (period $t=0$ in the model of the previous section). ${ }^{3}$ Therefore, the sample is further restricted to those who had a full-time job at some point between 16 and 21 and who were not bound by the minimum wage when they first entered the labour market. The latter restriction ensures that an estimate of each worker's initial marginal revenue product is obtained.

\footnotetext{
${ }^{3}$ During the sample period, young people were allowed to leave school during the school year in which they turned 16.
} 
Table 1

Descriptive statistics for the estimation sample

\begin{tabular}{lccc}
\hline Variable & All workers & Bound workers & Unbound workers \\
\hline Change in wage & 0.442 & 0.336 & 0.455 \\
Youth wage gap & 0.090 & 0.827 & 0 \\
Contemporaneous wage gap & 0.014 & 0.035 & 0.012 \\
Real wage & 11.967 & 9.990 & 12.209 \\
Collective agreement & 0.461 & 0.400 & 0.468 \\
Male & 0.578 & 0.625 & 0.573 \\
Age & 25.440 & 25.021 & 25.491 \\
\hline Sample size & 66,158 & 7,023 & 59,135 \\
\hline
\end{tabular}

Notes: ASHE survey weights are used.

The empirical analysis follows the approach used by Linneman (1982) and Currie and Fallick (1996), which involves the construction of a treatment variable measuring how much extra an employer must pay to retain a current employee after a minimum wage increase. The treatment variable, $W A G E G A P_{i}$, measures the cumulative effect of all minimum wage increases between 16 and 21 on person $i$. It is defined as follows, where $A G E_{i t}$ is the person's age in year $t, w_{i t}$ is his/her current hourly wage (in 2012 pounds, adjusted using the RPI) and $\bar{w}_{i(t+1)}$ is the relevant minimum wage in the following year (taking into account the worker's age):

$W A G E G A P_{i}=\sum_{16 \leq A G E_{i t} \leq 21} \max \left\{\bar{w}_{i(t+1)}-w_{i t}, 0\right\}$.

About $13 \%$ of the workers in the sample (accounting for $11 \%$ of the observations) were bound by the minimum wage sometime between ages 16 and 21. Means for the main variables used in the analysis are given in Table 1, separately for those workers who were bound by the minimum wage before age 22 and those who were not. Compared to the unbound workers, the bound workers earn less, are more likely to be male and are less likely to have job with a collective agreement. Among bound workers, average annual wage growth was 34 pence, whereas among the unbound workers, it was 46 pence. Figure 2 plots average wage growth by age for the two groups of workers. Wage growth declines with age for both groups, but it is consistently higher among the unbound workers up to age $27 .{ }^{4}$ The next section examines whether this difference persists, once the effects of other determinants of wage growth are controlled for.

\footnotetext{
${ }^{4}$ The difference in wage growth is statistically significant at ages 22, 23, 25 and 26.
} 
Figure 2

Mean wage growth for unbound and bound workers

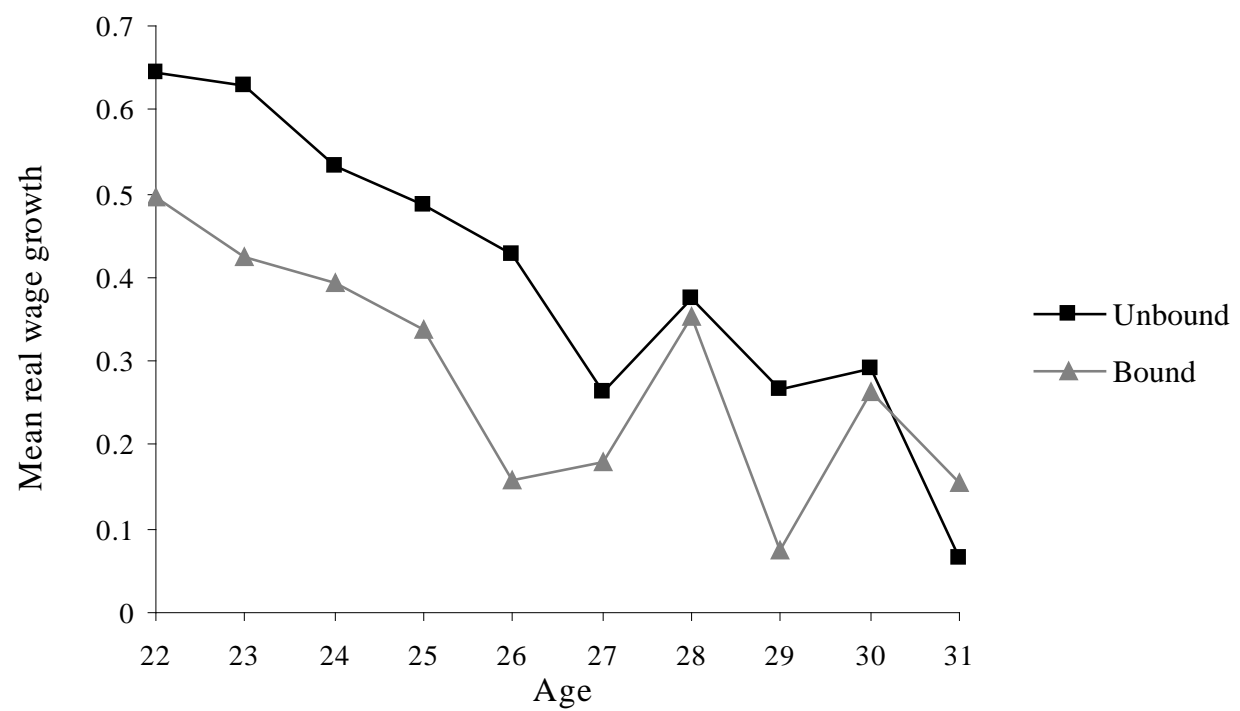

Notes: Bound workers are those workers who had a positive wage gap value for any year between ages 16 and 21.

ASHE survey weights are used.

\section{Analysis}

The empirical strategy is to compare the wage growth rates of otherwise identical workers who have different values of WAGEGAP because they entered the labour market at different points in time and hence were subject to different values of the minimum wage during their youth. The wage gap will vary for a number of reasons: the overall introduction of the national minimum wage in 1999, the introduction of the 16-17 and apprentice rates, the lowering of the age of eligibility for the adult rate and the annual increases in all rates by different amounts.

To begin with, the following basic specification is used:

$\Delta w_{i(t+1)}=\alpha_{0}+\alpha_{1} W_{A G E G A P}+\alpha_{2} w_{i}+\alpha_{3} A G E_{i t}+\mathbf{X}_{i t} \gamma+\lambda_{t}+u_{i t}$.

where $w_{i}$ is a person's real wage during his/her first year in full-time work (between ages 16 and 21) and controls for differences in wage growth that are due to differences in inherent productivity across people. Hence, the specification compares workers who initially earn the same wage, but who enter the labour market in different years and therefore experience different wage growth before 21 due to changes in the minimum wage. AGE is included as a proxy for the $\gamma$ terms in equation 15. $\mathbf{X}$ is a vector of control variables, comprising a person's wage gap in year $t$ (that 
Table 2

Results for wage growth regressions

\begin{tabular}{|c|c|c|c|c|}
\hline \multirow[t]{2}{*}{ Variable } & \multicolumn{2}{|c|}{ All observations } & \multirow{2}{*}{$\frac{\text { Aged 22-26 }}{\text { (iii) }}$} & \multirow{2}{*}{$\frac{\text { Aged 27-31 }}{\text { (iii) }}$} \\
\hline & (i) & (ii) & & \\
\hline \multirow[t]{2}{*}{ Youth wage gap } & -0.048 & $-0.101^{*}$ & $-0.137 * *$ & 0.034 \\
\hline & $(0.033)$ & $(0.053)$ & $(0.069)$ & $(0.053)$ \\
\hline \multirow{2}{*}{$\begin{array}{l}\text { Youth wage gap on collective } \\
\text { agreement jobs }\end{array}$} & - & $0.111^{*}$ & $0.156 * *$ & -0.057 \\
\hline & - & $(0.059)$ & $(0.072)$ & $(0.075)$ \\
\hline \multirow[t]{2}{*}{ Initial real wage } & $0.022 *$ & $0.022 *$ & $0.038 * *$ & -0.017 \\
\hline & $(0.011)$ & $(0.011)$ & $(0.017)$ & $(0.036)$ \\
\hline \multirow{2}{*}{ Contemporaneous wage gap } & $1.831 * * *$ & $1.832 * * *$ & $1.667 * * *$ & $2.419 * * *$ \\
\hline & $(0.092)$ & $(0.092)$ & $(0.089)$ & $(0.282)$ \\
\hline \multirow[t]{2}{*}{ Male } & $0.115 * * *$ & $0.115^{* * *}$ & $0.148 * * *$ & 0.053 \\
\hline & $(0.020)$ & $(0.020)$ & $(0.029)$ & $(0.062)$ \\
\hline \multirow[t]{2}{*}{ Age } & $-0.030 * * *$ & $-0.030 * * *$ & $-0.039 * * *$ & -0.009 \\
\hline & $(0.006)$ & $(0.006)$ & $(0.010)$ & $(0.027)$ \\
\hline \multirow[t]{2}{*}{ Collective agreement } & $-0.062 * * *$ & $-0.063 * * *$ & $-0.110 * * *$ & 0.031 \\
\hline & $(0.022)$ & $(0.022)$ & $(0.037)$ & $(0.080)$ \\
\hline R-squared & 0.013 & 0.013 & 0.019 & 0.009 \\
\hline Sample size & 66,158 & 66,158 & 44,778 & 21,380 \\
\hline
\end{tabular}

Notes: All regressions include a full set of region (12 categories) and year (13 categories) dummies. Standard errors are clustered by person and are presented in parentheses. *, ** and *** denote significance at the $10 \%, 5 \%$ and $1 \%$ level, respectively.

is, $\left.\max \left\{\bar{w}_{i(t+1)}-w_{i t}, 0\right\}\right)$ and dummy variables for whether the person is male and whether the wage on his/her job is set by a collective agreement. The contemporaneous wage gap controls for the possibility that workers' wages will grow because they continue to be bound by the minimum wage after age 21 . The collective agreement dummy controls for the possibility that wage growth may be lower in cases where unions act to compress the wage distributions (Freeman and Medoff 1984). $\lambda$ is a year fixed effect and $u$ is an error term. All standard errors are clustered by person.

The first column of Table 2 presents the results of estimating equation 16 using the ASHE sample. The youth wage gap (WAGEGAP) has an insignificant coefficient, but the initial real wage has a significant positive effect. This suggests that the negative relationship between wage growth and the minimum wage seen in Figure 2 is the result of minimum wage workers having lower wage growth than those earning slightly more. Among the control variables, the contemporaneous wage gap has a coefficient that is significantly larger than the value of 1 predicted, men and those on non-collective agreement jobs are found to have significantly greater wage growth than others and wage growth is found to decline with age.

Although WAGEGAP has no overall effect on wage growth, the theory in Section 2 predicts that it should only have an unambiguously negative effect on wage growth 
in the competitive sector. To examine this, the analysis draws on a question in the ASHE which asks whether a worker's pay was "set with reference to an agreement affecting more than one employee”, for example, agreements with trade unions or workers' committees. Since these pay agreements involve bargaining between firms and worker groups, they may be characterised as constituting the non-competitive sector of the labour markets. ${ }^{5}$

A wage gap was calculated, taking into account only those cases in which a worker was covered by a collective agreement between ages 16-21, as follows:

COLAGWAGEGAP $P_{i}=\sum_{16 \leq A G E_{i t} \leq 21} C O L A G_{i t} \times \max \left\{\bar{w}_{i(t+1)}-w_{i t}, 0\right\}$,

where COLAG is a dummy for whether a worker was covered by a collective agreement in a given year. In order to allow the coefficient on WAGEGAP in equation 16 to vary according to what sector a person worked in, COLAGWAGEGAP was added as a regressor:

$$
\begin{aligned}
\Delta w_{i(t+1)}=\delta_{0}+\delta_{1} \text { WAGEGAP }_{i}+\delta_{2} \text { COLAGWAGEGAP }_{i}+\delta_{3} w_{i} & +\delta_{4} A G E_{i t} \\
& +\mathbf{X}_{i t} \boldsymbol{\varphi}+\mu_{t}+v_{i t} .
\end{aligned}
$$

A significant estimate of $\delta_{2}$ in equation 18 indicates a difference in the relationship between wage growth and the wage gap in the competitive and noncompetitive sectors. As seen in the third column of Table 2, the overall wage gap has a significant negative coefficient, indicating that the minimum wage has a negative effect on wage growth among those workers who were not covered by a collective agreement. The value of this indicates that a wage increase of $£ 1$ between the ages of 16 and 21 brought about by the minimum wage will result in a 9 pence decrease in annual wage growth after $21 .{ }^{6}$ However, consistent with theory, the effect of the wage gap is significantly different for those workers who were covered by a collective agreement before 22 and the overall effect of the wage gap is insignificant for these workers.

The assumption of decreasing returns to training (implied by the shape of $\beta$ in the model) means that the effect of the wage gap should fall as a worker ages. To examine this, the regression was run separately for workers aged 22-26 and 27-31 (see

\footnotetext{
${ }^{5}$ Acemoglu and Pischke's model implies that jobs without collective agreements might still exhibit a positive relationship between training and the minimum wage if competition is imperfect.

${ }^{6}$ Taking into account equations 8 and 14, this result implies that every pound of training before age 21 yields benefits that grow by 9 pence a year between ages 22 and 31 on average.
} 
columns three and four in Table 2). As predicted, the coefficients on WAGEGAP and COLAGWAGEGAP were much stronger among the younger group. A binding $£ 1$ increase in the minimum wage between 16 and 21 is found to yield a 13 pence decrease in annual wage growth between 22 and 26, but no effect on wage growth between 27 and 31.

Overall, the results suggest that the existence of the development rate has raised wage growth among low-wage workers. Compared to a scenario in which the adult minimum wage applied to all workers aged 18 and over, the average worker who was bound by the development rate experienced 5.5 pence (or $17 \%$ at the mean) higher wage growth between ages 22 and 31. However, among those with non-collective agreement jobs only, the effect is 6.4 pence (or $20 \%$ at the mean).

\section{Robustness checks}

The model presented in Section 4 implies that there should be a U-shaped relationship between wage growth and the wage gap when the labour market is noncompetitive. To examine whether the insignificant overall effect of the collective agreement wage gap (that is, $\delta_{1}+\delta_{2}$ ) found in Table 2 obscures a U-shaped relationship, the coefficients on the wage gap measures are allowed to vary by quartile. As seen in the first column of Table 3, the results provide some evidence of a divergence in the wage gap effect between the collective agreement and noncollective agreement groups when the wage gap is large, although most of the coefficients are insignificant. Figure 3 plots the predicted level of wage growth across the wage gap quartiles, holding all other variables at their means. The wage gap has a monotonic negative effect on wage growth in collective agreement jobs but a Ushaped effect on wage growth in non-collective agreement jobs, consistent with the expected pattern illustrated in Figure 1.

Collective agreement jobs and non-collective agreement jobs are not randomly distributed. As a consequence, it is possible that the significant difference between the estimates of $\delta_{1}$ and $\delta_{2}$ in equation 18 simply reflects the fact that collective agreement jobs tend to be in those occupations which provide more general training anyway. To control for this, dummies for a person's four-digit occupation at the time he/she entered the labour market are added to the regression. Occupation data are only available from 2002, so the sample is restricted to those who entered the labour 
Table 3

Additional results for wage growth regressions

\begin{tabular}{|c|c|c|c|c|}
\hline Variable & (i) & (ii) & (iii) & (iv) \\
\hline Youth wage gap quartile 1 & $\begin{array}{l}-0.017 \\
(0.051)\end{array}$ & - & - & - \\
\hline Youth wage gap quartile 2 & $\begin{array}{l}-0.030 \\
(0.053)\end{array}$ & - & - & - \\
\hline Youth wage gap quartile 3 & $\begin{array}{l}-0.100 \\
(0.064)\end{array}$ & - & - & - \\
\hline Youth wage gap quartile 4 & $\begin{array}{c}-0.139 * \\
(0.072)\end{array}$ & - & - & - \\
\hline $\begin{array}{l}\text { Youth wage gap on collective } \\
\text { agreement jobs quartile } 1\end{array}$ & $\begin{array}{c}0.056 \\
(0.094)\end{array}$ & - & - & - \\
\hline $\begin{array}{l}\text { Youth wage gap on collective } \\
\text { agreement jobs quartile } 2\end{array}$ & $\begin{array}{l}-0.079 \\
(0.078)\end{array}$ & - & - & - \\
\hline $\begin{array}{l}\text { Youth wage gap on collective } \\
\text { agreement jobs quartile } 3\end{array}$ & $\begin{array}{l}0.167 * \\
(0.086)\end{array}$ & - & - & - \\
\hline $\begin{array}{l}\text { Youth wage gap on collective } \\
\text { agreement jobs quartile } 4\end{array}$ & $\begin{array}{c}0.138 \\
(0.094)\end{array}$ & - & - & - \\
\hline Youth wage gap & - & $\begin{array}{c}-0.087 * * \\
(0.041)\end{array}$ & $\begin{array}{c}-0.138 * * \\
(0.061)\end{array}$ & $\begin{array}{c}-0.091 * \\
(0.051)\end{array}$ \\
\hline $\begin{array}{l}\text { Youth wage gap on collective } \\
\text { agreement jobs }\end{array}$ & - & $\begin{array}{c}0.172 * * * \\
(0.060)\end{array}$ & $\begin{array}{l}0.230 * * \\
(0.093)\end{array}$ & $\begin{array}{c}0.167 * * \\
(0.072)\end{array}$ \\
\hline $\begin{array}{l}\text { Youth wage gap } \times \text { collective } \\
\text { agreement }\end{array}$ & - & - & $\begin{array}{c}0.123 \\
(0.083)\end{array}$ & - \\
\hline $\begin{array}{l}\text { Youth wage gap on collective } \\
\text { agreement jobs } \times \text { collective agreement }\end{array}$ & - & - & $\begin{array}{l}-0.137 \\
(0.124)\end{array}$ & - \\
\hline Youth wage gap $\times$ same occupation & - & - & - & $\begin{array}{c}0.013 \\
(0.079)\end{array}$ \\
\hline $\begin{array}{l}\text { Youth wage gap on collective } \\
\text { agreement jobs } \times \text { same occupation }\end{array}$ & - & - & - & $\begin{array}{c}0.027 \\
(0.132)\end{array}$ \\
\hline Initial real wage & $\begin{array}{l}0.022^{*} \\
(0.011)\end{array}$ & $\begin{array}{l}-0.004 \\
(0.008)\end{array}$ & $\begin{array}{l}-0.004 \\
(0.008)\end{array}$ & $\begin{array}{l}-0.004 \\
(0.008)\end{array}$ \\
\hline Contemporaneous wage gap & $\begin{array}{l}1.831 * * * \\
(0.092)\end{array}$ & $\begin{array}{c}1.630 * * * \\
(0.154)\end{array}$ & $\begin{array}{c}1.632 * * * \\
(0.155)\end{array}$ & $\begin{array}{c}1.630 * * * \\
(0.155)\end{array}$ \\
\hline Male & $\begin{array}{c}0.115^{* * *} \\
(0.020)\end{array}$ & $\begin{array}{c}0.096 * * \\
(0.039)\end{array}$ & $\begin{array}{c}0.096 * * \\
(0.039)\end{array}$ & $\begin{array}{c}0.096^{* *} \\
(0.039)\end{array}$ \\
\hline Age & $\begin{array}{l}-0.030 * * * \\
(0.006)\end{array}$ & $\begin{array}{c}-0.023^{* *} \\
(0.010)\end{array}$ & $\begin{array}{l}-0.024^{* *} \\
(0.010)\end{array}$ & $\begin{array}{c}-0.023^{* *} \\
(0.010)\end{array}$ \\
\hline Collective agreement & $\begin{array}{c}-0.063 * * * \\
(0.022)\end{array}$ & $\begin{array}{l}-0.039 \\
(0.034)\end{array}$ & $\begin{array}{l}-0.047 \\
(0.035)\end{array}$ & $\begin{array}{l}-0.039 \\
(0.034)\end{array}$ \\
\hline Initial occupation dummies & No & Yes & Yes & Yes \\
\hline $\begin{array}{l}\text { R-squared } \\
\text { Sample size }\end{array}$ & $\begin{array}{c}0.013 \\
66,158\end{array}$ & $\begin{array}{c}0.059 \\
18,660\end{array}$ & $\begin{array}{c}0.059 \\
18,660\end{array}$ & $\begin{array}{c}0.059 \\
18,660\end{array}$ \\
\hline
\end{tabular}

Notes: All regressions include a full set of region (12 categories) and year (13 categories) dummies. Standard errors are clustered by person and are presented in parentheses. *, ** and *** denote significance at the $10 \%, 5 \%$ and $1 \%$ level, respectively.

market after this point. As seen in the second column of Table 3, this has little effect on the coefficients and the results are stronger than in Table 2. Even within narrowlydefined occupational groups, having a non-collective agreement job results in significantly lower wage growth later in a worker's career, compared to workers on collective agreement jobs with the same wage gap. 
Figure 3

Predicted wage growth by sector

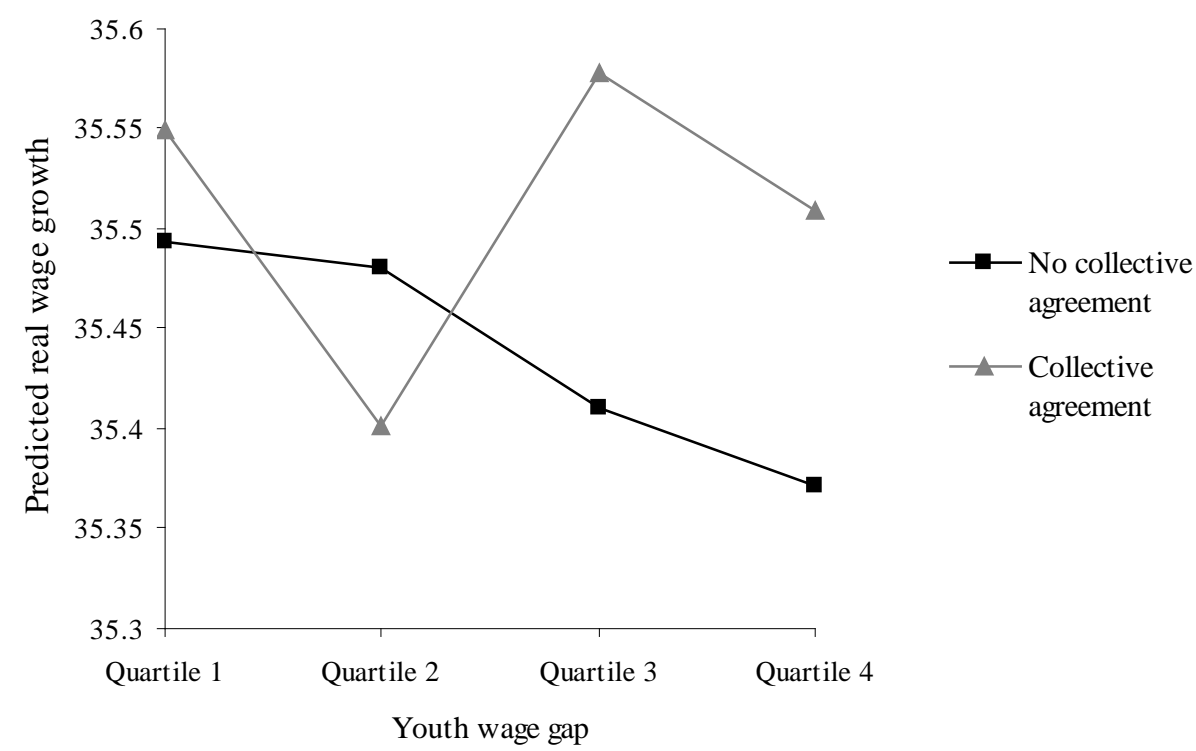

Notes: Coefficients are taken from specification (i) in Table 3, holding all other variables at their means across the full sample.

Grossberg and Sicilian (1999) and Neumark and Wascher (2001) pointed out that the minimum wage might flatten the age-earnings profile not because of any change in training levels but because firms may be forced to abandon the use of delayed compensation schemes. To examine whether this is responsible for the pattern observed among non-collective agreement jobs, WAGEGAP and COLAGWAGEGAP are interacted with a worker's current collective agreement job status and added to the regression (as well as the initial occupation dummies). If the reduction in wage growth is driven by reductions in individual productivity, it should not matter whether a worker changes sector after age 21 (at which age it is assumed all general training has been acquired). However, if firms in the competitive sector choose to flatten the age-earnings profile in response to increases in the minimum wage, workers should only experience reductions in wage growth while they remain in that sector. The results (reported in the third column of Table 3) indicate that the wage gap coefficients do not vary significantly when a worker changes sector, thus suggesting that reductions in productivity do occur when the minimum wage is raised. Similarly, the results are not found to vary according to whether a person has changed occupation since he/she entered the labour market (see the fourth column of Table 3). In both cases, it appears that a worker is permanently affected by exposure to the 
Table 4

Results for wage regressions using different training age ranges

\begin{tabular}{lcccc}
\hline Variable & \multicolumn{4}{c}{ Training age range } \\
\cline { 2 - 4 } & $16-18$ & $16-19$ & $16-20$ & $16-21$ \\
\hline Youth wage gap & $-0.083^{*}$ & $-0.112^{* *}$ & -0.046 & $-0.101^{*}$ \\
& $(0.050)$ & $(0.052)$ & $(0.050)$ & $(0.053)$ \\
Youth wage gap on collective & $0.106^{*}$ & $0.105^{*}$ & 0.071 & $0.111^{*}$ \\
agreement jobs & $(0.060)$ & $(0.059)$ & $(0.053)$ & $(0.059)$ \\
\hline R-squared & 0.037 & 0.009 & 0.011 & 0.013 \\
Sample size & 14,746 & 29,312 & 45,665 & 66,158 \\
\hline
\end{tabular}

Notes: All regressions include initial real wage, contemporaneous wage gap, male, age, collective agreement and a full set of region (12 categories) and year (13 categories) dummies.

Standard errors are clustered by person and are presented in parentheses. ${ }^{*}, * *$ and $* * *$ denote significance at the $10 \%, 5 \%$ and $1 \%$ level, respectively.

minimum wage when young, which is inconsistent with a situation in which certain firms alter their pay policies in response to changes in the minimum wage.

In the results presented so far, all work done before age 22 is included in the calculation of the wage gap measures and all workers who commenced full-time work before this age are included in the sample. Some of these workers will have attained tertiary qualifications and therefore will constitute a poor control group for the minimum wage workers of interest in this study. ${ }^{7}$ To examine how robust the results are to this decision, lower age cut-offs were used. Table 4 reveals that the coefficients on WAGEGAP and COLAGWAGEGAP remain significant when 19 and 20 are used as cut-off ages, but not 21 .

\section{Mechanisms}

Although the ASHE data do not include a measure of training, it is possible to examine whether the negative relationship that has been uncovered between wage growth and the wage gap in the competitive sector reflects reductions in levels of human capital. Table 5 decomposes the overall results for wage growth into the effects the wage gap has on the individual components of wage growth, namely growth in base pay, incentive pay (which includes bonuses, incentive pay, piecework and commission), shift and premium pay and overtime pay (the residual 'other pay' component is excluded). ${ }^{8}$ All are expressed as per hour rates. Although the coefficients on WAGEGAP and COLAGWAGEGAP have the same sign in each

\footnotetext{
${ }^{7}$ No information on education is available in the ASHE.

${ }^{8}$ Since incentive pay and shift pay were only provided in the ASHE dataset from 2000, observations for this year onwards were used in these regressions.
} 
Table 5

Results using components of wage growth

\begin{tabular}{|c|c|c|c|c|}
\hline Variable & $\begin{array}{c}\text { (i) } \\
\text { Base pay }\end{array}$ & $\begin{array}{c}\text { (ii) } \\
\text { Incentive pay }\end{array}$ & $\begin{array}{c}\text { (iii) } \\
\text { Shift pay }\end{array}$ & $\begin{array}{c}\text { (iii) } \\
\text { Overtime pay }\end{array}$ \\
\hline Youth wage gap & $\begin{array}{c}-0.035 \\
(0.027)\end{array}$ & $\begin{array}{c}-0.020^{* *} \\
(0.008)\end{array}$ & $\begin{array}{l}-0.003 \\
(0.004)\end{array}$ & $\begin{array}{c}-0.044 \\
(0.043)\end{array}$ \\
\hline $\begin{array}{l}\text { Youth wage gap on collective } \\
\text { agreement jobs }\end{array}$ & $\begin{array}{c}0.017 \\
(0.037)\end{array}$ & $\begin{array}{c}0.019 \\
(0.012)\end{array}$ & $\begin{array}{c}0.002 \\
(0.006)\end{array}$ & $\begin{array}{c}0.067 \\
(0.044)\end{array}$ \\
\hline Initial real wage & $\begin{array}{c}0.029 * * * \\
(0.011)\end{array}$ & $\begin{array}{l}-0.007 * * * \\
(0.002)\end{array}$ & $\begin{array}{l}-0.001 \\
(0.001)\end{array}$ & $\begin{array}{c}0.001 \\
(0.001)\end{array}$ \\
\hline Contemporaneous wage gap & $\begin{array}{c}1.723^{* * *} \\
(0.096)\end{array}$ & $\begin{array}{c}0.046 * * \\
(0.025)\end{array}$ & $\begin{array}{c}0.023^{* *} \\
(0.010)\end{array}$ & $\begin{array}{c}0.046 * * * \\
(0.016)\end{array}$ \\
\hline Male & $\begin{array}{c}0.082^{* * *} \\
(0.017)\end{array}$ & $\begin{array}{c}0.012 \\
(0.009)\end{array}$ & $\begin{array}{c}0.004 \\
(0.003)\end{array}$ & $\begin{array}{l}0.010^{*} \\
(0.005)\end{array}$ \\
\hline Age & $\begin{array}{c}-0.021 * * * \\
(0.005)\end{array}$ & $\begin{array}{l}-0.001 \\
(0.002)\end{array}$ & $\begin{array}{c}-0.001^{*} \\
(0.001)\end{array}$ & $\begin{array}{c}-0.004 * * * \\
(0.001)\end{array}$ \\
\hline Collective agreement & $\begin{array}{c}-0.068 * * * \\
(0.019) \\
\end{array}$ & $\begin{array}{c}0.003 \\
(0.010) \\
\end{array}$ & $\begin{array}{l}-0.002 \\
(0.003)\end{array}$ & $\begin{array}{c}0.000 \\
(0.007) \\
\end{array}$ \\
\hline $\begin{array}{l}\text { R-squared } \\
\text { Sample size }\end{array}$ & $\begin{array}{c}0.013 \\
63,874\end{array}$ & $\begin{array}{c}0.001 \\
63,874\end{array}$ & $\begin{array}{c}0.001 \\
63.874\end{array}$ & $\begin{array}{c}0.001 \\
63,874\end{array}$ \\
\hline
\end{tabular}

Notes: All regressions include a full set of region (12 categories) and year (13 categories) dummies. Standard errors are clustered by person and are presented in parentheses. *, ** and *** denote significance at the $10 \%, 5 \%$ and $1 \%$ level, respectively.

regression, most of the results are insignificant. However, WAGEGAP has a significant negative effect on growth in incentive pay. Since this is the component of pay that is most closely tied to a worker's productivity, this result further reinforces the notion that increases in the minimum wage reduce productivity in the competitive sector.

In Table 6, additional dependent variables are used in place of wage growth in equation 18. In the first column, the dependent variable is a dummy variable for whether a worker stayed at the same firm in the following year. The wage gap is found to have a significant negative effect on the likelihood of remaining at the same firm for workers who were not covered by a collective agreement as youths, but an insignificant effect for workers who were covered by a collective agreement. Similar results are found when the likelihood of remaining on the same job is considered (as shown in the second column of Table 6). Once again, these results are consistent with competitive sector workers experiencing reductions in human capital when the minimum wage rises. Being bound by the minimum wage as a youth is also found to have a negative effect on the likelihood of switching from a non-managerial to a 
Table 6

Results for job change regressions

\begin{tabular}{lccc}
\hline Variable & (i) & (ii) & (iii) \\
& Remain with firm & Remain in job & Promoted to manager \\
\hline Youth wage gap & -0.006 & -0.005 & $-0.009^{* *}$ \\
& $(0.005)$ & $(0.005)$ & $(0.004)$ \\
Youth wage gap on collective & $0.014^{*}$ & $0.016^{* *}$ & -0.001 \\
agreement jobs & $(0.007)$ & $(0.008)$ & $(0.006)$ \\
\hline R-squared & 0.056 & 0.056 & 0.005 \\
Sample size & 69,441 & 69,443 & 32,242 \\
\hline
\end{tabular}

Notes: All regressions include initial real wage, contemporaneous wage gap, male, age, collective agreement and a full set of region (12 categories) and year (13 categories) dummies.

Standard errors are clustered by person and are presented in parentheses. *, ** and *** denote significance at the $10 \%, 5 \%$ and $1 \%$ level, respectively.

managerial role (reported in the third column). ${ }^{9}$ However, this is not found to differ by whether a person was covered a collective agreement as a youth or not.

\section{Conclusion}

This paper has examined whether the minimum wage leads to lower wage growth later in a worker's career. Becker's (1962) seminal work demonstrated that in a perfectly competitive labour market, firms should cut back on training for workers whenever they are required to raise wages because of an increase in the minimum wage. However, as noted by Acemoglu and Pischke (2003), when the labour market is not perfectly competitive, firms might find it profitable to increase training in response to an increase in the minimum wage for some workers. A simple model of training and profit maximisation predicts that being paid the minimum wage when young should lead to lower wage growth thereafter for those who work in competitive sectors of the labour market, but that there should be a U-shaped relationship between the minimum wage and wage growth for those who were in non-competitive sectors. Data from the Annual Survey of Hours and Earnings in the UK find support for both predictions, thus reconciling the contrasting predictions of Becker and Acemoglu and Pischke. Workers who received large wage gains due to the minimum wage before the age of 22 experience lower wage growth between the ages of 22 and 31 . However, this effect is only found for those who were not covered by a collective agreement before 22; the relationship is insignificant for those who were covered by a collective agreement. The results provide evidence in favour of having a lower rate of the

\footnotetext{
${ }^{9}$ This regression was restricted to only those workers who were initially not in jobs that involved managerial responsibilities. Data on managerial responsibilities are only available for 2003-2011.
} 
minimum wage for those aged under 22, but that this only benefits those working in the competitive sector of the labour market.

\section{References}

Acemoglu, Daron, and Jörn-Steffen Pischke. 1999. 'The structure of wages and investment in general training.' Journal of Political Economy, 107(3), 539-572.

Acemoglu, Daron, and Jörn-Steffen Pischke. 2003. 'Minimum wages and on-the-job training.’ Research in Labor Economics, 22: 159-202.

Arulampalam, Wiji, Alison L. Booth and Mark L. Bryan. 2004. 'Training and the new minimum wage.’ Economic Journal, 114(494): C87-C94.

Becker, Gary S. 1962. 'Investment in human capital: A theoretical analysis.' Journal of Political Economy, 70(5): 9-49.

Becker, Gary S. 2009. Human capital, $3^{\text {rd }}$ edition. Chicago, IL: University of Chicago Press.

Brown, Charles. 1999. 'Minimum wages, employment and the distribution of income.' In (Orley Ashenfelter and David Card, eds) Handbook of Labor Economics, vol. 3. Amsterdam: North Holland.

Currie, Janet, and Bruce C. Fallick. 1996. 'The minimum wage and the employment of youth: Evidence from the NLSY.' Journal of Human Resources, 31(2): 404428.

Eyraud, François, and Catherine Saget. 2005. The fundamentals of minimum wage fixing. Geneva: International Labour Office.

Fairris, David, and Roberto Pedace. 2004. 'The impact of minimum wages on job training: An empirical exploration with establishment data.' Southern Economic Journal, 70(3): 566-583.

Freeman, Richard, and James Medoff. 1984. What do unions do? New York: Basic Books.

Grossberg, Adam J., and Paul Sicilian. 1999. 'Minimum wages, on-the-job training, and wage growth.' Southern Economic Journal, 65(3): 539-556.

Hashimoto, Masanori. 1982. 'Minimum wage effects on training on the job.' American Economic Review, 72(5): 1070-1087.

Lazear, Edward P. 1979. 'Why is there mandatory retirement?' Journal of Political Economy 87(6): 1261-1284. 
Lazear, Edward P., and Frederick H. Miller, 1981. 'Minimum wage versus minimum compensation.' In Report of the Minimum Wage Study Commission, vol. 5, 347381. Washington, DC: US Government Printing Office.

Leighton, Linda, and Jacob Mincer. 1981. 'The effects of minimum wages on human capital formation.' In (Simon Rottenberg, ed.) The Economics of Legal Minimum Wages, 155-173, Washington DC: American Enterprise Institute.

Linneman, Peter. 1982. 'The economic impacts of minimum wage laws: A new look at an old question.' Journal of Political Economy, 90(3): 443-469.

Neumark, David, and William Wascher. 2001. 'Minimum wages and training revisited.' Journal of Labor Economics, 19(3): 563-595.

Office for National Statistics. 2013. Annual Survey of Hours and Earnings, 19972012: Secure Access [computer file]. 4th Edition. Colchester, Essex: UK Data Archive [distributor], June 2013. SN: 6689.

Rosen, Sherwin. 1972. 'Learning and experience in the labor market.' Journal of Human Resources, 7(3): 326-342.

Schiller, Bradley R. (1994). 'Moving up: The training and wage gains of minimum wage entrants.' Social Science Quarterly, 75(3), 622-636.

Simpson, Wayne. 1984. 'An econometric analysis of industrial training in Canada.' Journal of Human Resources, 19(4), 435-451. 